\title{
Genetic parameters for Finnish blue fox population: litter size, age at first insemination and pelt size
}

\author{
Jussi Peura \\ MTT Agrifood Research Finland, Biotechnology and Food Research, Biometrical Genetics, \\ FI-31600 Jokioinen, Finland. Current address: Pig test station, Mettisuontie 49, FI-35400 Längelmäki, Finland, \\ e-mail: jussi.peura@faba.fi \\ Ismo Strandén, Esa A. Mäntysaari \\ MTT Agrifood Research Finland, Biotechnology and Food Research, Biometrical Genetics, \\ FI-31600 Jokioinen, Finland
}

\begin{abstract}
Pelt size has increased rapidly in the Finnish blue fox population during the last decade. However, average number of pups per mated female has slightly decreased after the mid-1990's. In this study we estimated genetic parameters of litter size in the first two parturitions, age of female at first insemination, and pelt size with a linear multitrait animal model. Heritability of litter size in first and second parturition was 0.06 and 0.10 , respectively. Heritability estimate for age at first insemination was 0.15 and for pelt size 0.29 . Genetic correlation between pelt size and first litter size was -0.30 , between first and second litter size 0.76 , and between second litter size and age at first insemination 0.70 . Thus, genetic correlation between fertility and pelt size was unfavorable.
\end{abstract}

Key-words: fertility, fur animals, genetic correlations, heritability, pelt size, variance components

\section{Introduction}

Main goals in blue fox breeding are to increase litter and pelt sizes, and improve fur quality. Most weight has been given to pelt size (PS) because of its high economic importance (Lohi 2004, Peura et al. 2004a). Consequently, average PS has increased considerably during the last $10-15$ years. While the skin size has increased, the average number of pups per mated female has decreased slightly after mid-1990's. Because genetic correlation between PS and fertility has been estimated only in few studies, correlated change in fertility due to selection on PS is unclear. Peura et al. (2004b) 
Vol. 16 (2007): 136-146

estimated unfavorable genetic correlation between animal size (subjectively graded) and first $(-0.40)$, second $(-0.40)$, and third $(-0.23)$ litter size (LS). Lagerkvist et al. (1994) found unfavorable genetic correlation between female kit body weight (measured in September) and kit mortality in the following suckling period. In addition, Peura et al. (2005) estimated high genetic correlation between animal size and pelt size (0.74).

Age of female at first insemination (AFI) indicates age of female sexual maturity. Only few estimates of heritability have been published for AFI in blue foxes. Peura et al. (2004b) estimated heritability of AFI to be between 0.16 and 0.18 for blue foxes. For pigs and dairy cattle, heritability of AFI ranges between 0.11 and 0.32 (Raheja et al. 1989, Hanenberg et al. 2001, Muir et al. 2004). In pig production and in dairy milk production, the main selection goal is to achieve economic benefit by shorter farrowing or calving interval. However, blue foxes are seasonal breeders and come into heat only once a year (Farstad 1992). Moreover, Peura (2004) concluded that too early or too late heat is associated with smaller LS.

Litter size for blue foxes is recorded usually at whelping, 2 to 3 weeks after whelping, or at weaning. Heritabilities for LS at whelping, at 2 to 3 weeks after whelping, and at weaning have been estimated to be 0.05-0.21 (Nordrum 1993, Nikula 2000, Wierzbicki 2004), 0.00-0.11 (Nordrum 1993, Nikula 2000, Peura et al. 2004b), and 0.21 (Wierzbicki 2004), respectively. Lagerkvist et al. (1994) estimated heritability of total number of pups born to be 0.09 in minks. For comparison, Serenius et al. (2004) estimated heritabilities to be between 0.07 and 0.11 for different LS traits in pigs.

Pelt and litter sizes along with fur quality are economically the most important traits in Finnish blue fox breeding. In order to define breeding goals properly, heritabilities and genetic correlations for PS and fertility traits are needed. Therefore, our objective was to estimate genetic (co) variances for LS, AFI, and PS. Second objective was to compare genetic parameters and standardized breeding value estimates calculated using different scales for the PS trait.

\section{Material and methods}

Pelt size and fertility data were sampled from the Finnish SAMPO register maintained by the Finnish Fur Breeders Association. The sampled animals were required to have a pedigree that gave suitable genetic links between farms. This criterion was fulfilled by selecting data and pedigree information from six farms which belonging to a breeding circle. Only purebred blue foxes were accepted. The sampled pedigree had 53720 animals born between years 1990 and 2002.

\section{Fertility traits}

The studied fertility traits were the litter size from first two parities LS1 and LS2, and AFI. Litter size observations from females with 1-20 pups after 2-3 weeks from whelping were accepted. However, LS observations from females mated with more than one male per breeding season were excluded. In order to avoid bias caused by pre-selection, the second litter size was excluded, if the first litter size was missing. Age at first insemination was defined as number of days between the birth and the first recorded mating. Observations before 274 (about $2.5 \%$ ) and after 367 (about $2.5 \%$ ) days of age were considered unreliable and were excluded.

\section{Pelt size measures}

Table 1 compares the PS measures given in two different transformed scales and the original auction house classes. In Finland, measurement of pelt length is based on automated sorting and measuring equipments (ATE-Applied Engineering Ltd, Finland 2003). Unfortunately the exact pelt length measure is not recorded. Instead, it is classified into 8 classes denoted by numbers from 3 to 50 (Table 1).

Increase in PS has lead to introduction of three additional classes for very long skins during the last two decades: 30 -class in 1988, 40-class in 


\section{AGRICULTURAL AND FOOD SCIENCE}

Peura, J. et al. Genetic parameters for Finnish blue fox population

Table 1. Scales used for describing pelt size in blue foxes. Original data are by classes, PS-FIN is the scale used in the current Finnish breeding scheme, and PS-DEV has been formed from the auction house classes.

\begin{tabular}{|c|c|c|c|c|c|c|c|c|c|c|c|c|c|c|c|}
\hline \multirow{3}{*}{$\begin{array}{l}\text { Auction } \\
\text { house } \\
\text { sorting } \\
\text { system } \\
\text { Class }\end{array}$} & \multirow[b]{3}{*}{$\mathrm{cm}$} & \multicolumn{14}{|c|}{ Corresponding classes in the analysis } \\
\hline & & \multirow[t]{2}{*}{ PS-FIN } & \multicolumn{13}{|c|}{ PS-DEV } \\
\hline & & & 1990 & 1991 & 1992 & 1993 & 1994 & 1995 & 1996 & 1997 & 1998 & 1999 & 2000 & 2001 & 2002 \\
\hline 3 & $70.1-79.0$ & 1 & & & -266 & & & & & & & & & & \\
\hline 2 & $79.1-88.0$ & 1 & -200 & -200 & & & & & & & & & & & \\
\hline 1 & $88.1-97.0$ & 1 & -100 & -99 & -106 & -104 & -108 & -99 & -100 & -95 & -87 & -81 & & & \\
\hline 0 & $97.1-106.0$ & 1 & 1 & 1 & 1 & 1 & 1 & 1 & 1 & 1 & 1 & 1 & 1 & 1 & 1 \\
\hline 20 & $106.1-115.0$ & 2 & 106 & 108 & 105 & 103 & 107 & 102 & 98 & 97 & 89 & 85 & 94 & 95 & 84 \\
\hline 30 & $115.1-124.0$ & 3 & 227 & 230 & 224 & 225 & 234 & 231 & 232 & 199 & 186 & 177 & 183 & 184 & 171 \\
\hline 40 & $124.1-133.0$ & 4 & & & & & & & & 317 & 304 & 274 & 279 & 279 & 267 \\
\hline 50 & $>133.0$ & 5 & & & & & & & & & & 384 & 390 & 392 & 380 \\
\hline
\end{tabular}

1997 and 50-class in 1999. This has had a large impact on proportion of pelts in the longest classes and, moreover, on average length of pelts in these classes. Therefore, two alternative transformation methods for PS were studied. In the first method (PS-FIN), original auction house scale was transformed to five classes from 1 to 5 (Table 1). This scale is the one currently used in the Finnish blue fox breeding scheme.

In the second method, denoted PS-DEV, the auction house categories were changed to be mean deviations from class 0 in each year. The distances between the classes were not one as in PS-FIN and were calculated using an assumed distribution of the exact PS measures in each year. The underlying PS was assumed to have a standard normal distribution. Mean deviation within a year for size class $j$ was calculated by formula:

$i_{j}=\frac{z\left(x_{j-1}\right)-z\left(x_{j}\right)}{p_{j}}$

where $p_{j}$ is proportion of pelts in size class $j$, and

$z\left(x_{j}\right)=\frac{1}{\sqrt{2 \pi}} e^{-x_{j}^{2} / 2}$

or the ordinate of the standard normal density function at truncation point $x_{j}$ dividing the classes $j$ and $j-1$. The proportions were taken from auction statistics of Finnish Fur Sales Ltd between 1990 and 2002. The mean deviations were transformed to be deviations from class 0 which was set to have value one. Finally, these mean deviations from class 0 were multiplied by 100 (Table 1 ).

\section{Statistical methods}

(Co)variance components were estimated with multitrait (4 traits) animal model using the DMU program (Madsen \& Jensen 2000) that calculates restricted maximum likelihood estimates for variance components. The model was:

$$
\mathbf{y}=\mathbf{X b}+\mathbf{W c}+\mathbf{Z a}+\mathbf{e}
$$

where $\mathbf{y}$ is vector of observations, $\mathbf{b}$ is vector of fixed effects, and $\mathbf{c}$, $\mathbf{a}$ and $\mathbf{e}$ are vectors of random litter, animal and residual effects, respectively. The fixed, litter, and animal effects are linked to appropriate observations by incidence matrices $\mathbf{X}, \mathbf{W}$ and $\mathbf{Z}$. Fixed effects for each trait are in Table 2.

The random effect vectors a, $\mathbf{c}$ and $\mathbf{e}$ were assumed to be independently and normally distributed with mean zero. In addition, $\operatorname{var}(\mathbf{a})=\mathbf{G}_{0} \otimes$ $\mathbf{A}$, where $\mathbf{A}$ is numerator relationship matrix, and $\mathbf{G}_{0}$ 
Vol. 16 (2007): 136-146

Table 2. Fixed effects in single and multitrait analysis for first and second litter sizes (LS), age at first insemination (AFI) and pelt size (PS-FIN and PS-DEV) in blue foxes.

\begin{tabular}{|c|c|c|c|c|}
\hline & \multicolumn{2}{|c|}{ LS } & \multirow[b]{2}{*}{ AFI } & \multirow[b]{2}{*}{ PS-FIN and PS-DEV } \\
\hline & $1^{\text {st }}$ & $2^{\text {nd }}$ & & \\
\hline Farm-year & $\mathrm{X}$ & $\mathrm{X}$ & $\mathrm{X}$ & $\mathrm{X}$ \\
\hline Time of birth (for animal) $)^{1)}$ & $\mathrm{X}$ & & $\mathrm{X}$ & $\mathrm{X}$ \\
\hline Mating method ${ }^{2)}$ & $\mathrm{X}$ & $\mathrm{X}$ & & \\
\hline Number of matings ${ }^{3)}$ & $\mathrm{X}$ & $\mathrm{X}$ & & \\
\hline Age of dam $\left.{ }^{4}\right)$ & & & & $\mathrm{X}$ \\
\hline \multicolumn{5}{|c|}{ 1) 4 classes (104-129, 130-144, 145-160 and 161-180 days from the beginning of the year) } \\
\hline \multicolumn{5}{|c|}{${ }^{2} 2$ classes (natural or artificial insemination) } \\
\hline \multicolumn{5}{|c|}{ 3) 2 classes ( 1 or $>1$ matings per season) } \\
\hline 4) 3 classes (1,2 or $3-15$ years old) & & & & \\
\hline
\end{tabular}

is genetic covariance matrix. Litter effects between animals were uncorrelated but correlated within animal between different traits. Thus, litter effects were assumed to be specific environmental effects common to pups of the same litter. Residual effects between animals were assumed to be independent. Residual correlations were estimated between traits within animal except for correlations involving PS. Heritability and the proportion of variation due to litter were calculated as

$$
\begin{aligned}
& h^{2}=\sigma_{a}^{2} /\left(\sigma_{a}^{2}+\sigma_{c}^{2}+\sigma_{e}^{2}\right) \text { and } \\
& c^{2}=\sigma_{c}^{2} /\left(\sigma_{a}^{2}+\sigma_{c}^{2}+\sigma_{e}^{2}\right),
\end{aligned}
$$

respectively, where $\sigma_{a}^{2}, \sigma_{c}^{2}$ and $\sigma_{e}^{2}$ are additive genetic, litter environment and residual variances of the considered trait, respectively.

PS-FIN and PS-DEV were compared using standardized estimates of breeding values. The model and assumptions were the same as in the variance component analysis and the variances were the estimates obtained there. Breeding values were standardized such, that animals born in 2000 had mean 100 and standard deviation 10. Average differences in these values were studied by year of birth.

\section{Results}

\section{Mean and variation}

Because PS is measured for all pups and fertility traits only for dams, number of observations for fertility traits was much less than for PS (Table 3). In addition, PS and fertility traits were never recorded on the same animal. Number of females having both LS1 and LS2 was 3418. Similarly, 3418 females had observations for both AFI and LS1, and 1796 females had observations for AFI and LS2.

Mean, standard deviation (s.d.), coefficient of variation $(\mathrm{CV})$, minimum and maximum in LS1 and LS2, AFI, PS-FIN and PS-DEV for the analyzed data are in Table 3. Average LS2 was about 2.7 pups more than LS1. The standard deviation of LS2 was slightly higher than that of LS1. Nevertheless, the CV in LS1 was slightly larger than in LS2 due to the smaller mean. The difference in CV between LS1 and LS2 is probably due to strong selection after LS1, and maturing of females.

Average AFI was 319 days or about 10.5 months. Standard deviation of AFI was quite low (11.3) which lead to considerably lower CV (0.04) than in other traits $(0.28-0.49)$. Mean PS-FIN was 3.11, and mean PS-DEV was about 212. As expected, CV was larger in PS-DEV than in PS-FIN. 
Peura, J. et al. Genetic parameters for Finnish blue fox population

\section{Population parameters}

Estimated heritabilities and proportions of variation of the spesific litter environment for the traits are in Table 4. Heritability estimate for LS1 was 0.06 and for LS2 0.10 . Proportion of litter variation was higher in LS2 than in LS1 (0.09 vs. 0.01). Heritability estimate for AFI was 0.15 . Effect of the specific environment for AFI variation was 0.26 , which is much larger than its heritability estimate. Heritability estimates for PS were 0.29, and effects of the specific environment were 0.08 and 0.09 , respectively, for PS-FIN and PS-DEV.

\section{Genetic correlations}

In the following, only correlations more than 1.96 times their SE will be considered being different

Table 3. Description of litter size and pelt size data in Finnish blue foxes.

\begin{tabular}{lcrrrrrr}
\hline Trait & Parity & \multicolumn{1}{c}{$\mathrm{N}^{5)}$} & Mean & \multicolumn{1}{c}{$\mathrm{SD}$} & $\mathrm{CV}^{6)}$ & Minimum & Maximum \\
\hline LS $^{1)}$ & 1 & 3623 & 5.83 & 2.88 & 0.49 & 1 & 16 \\
& 2 & 1806 & 8.54 & 3.27 & 0.38 & 1 & 18 \\
AFI $^{2)}$ & & 6147 & 319.01 & 11.25 & 0.04 & 266 & 361 \\
PS-FIN $^{3)}$ & & 44395 & 3.11 & 0.88 & 0.28 & 1 & 5 \\
PS-DEV $^{4)}$ & & 44395 & 212.3 & 87.14 & 0.41 & -266 & 392 \\
\hline 1)
\end{tabular}

1) number of pups 3 weeks after whelping

${ }^{2)}$ age at first insemination in days

${ }^{3)}$ pelt size in size points

4) pelt size in standard deviation units $* 100$

5) number of records

6) coefficient of variation.

Table 4. Estimated phenotypic variance $\left(\sigma_{P}^{2}\right)$, effect of common environment within litter $\left(\mathrm{c}^{2}\right)$, and heritability $\left(\mathrm{h}^{2}\right)$ with standard errors (s.e.) in first and second litter size (LS), age at first insemination (AFI) and pelt size for PS-FIN and PS-DEV.

\begin{tabular}{|c|c|c|c|c|c|c|c|}
\hline \multirow[b]{2}{*}{ Trait } & & \multicolumn{3}{|c|}{ PS-FIN } & \multicolumn{3}{|c|}{ PS-DEV } \\
\hline & & $\overline{\sigma_{P}^{2}}$ & $\mathrm{c}^{2} \pm$ s.e. & $\mathrm{h}^{2} \pm$ s.e. & $\sigma_{P}^{2}$ & $\mathrm{c}^{2} \pm$ s.e. & $\mathrm{h}^{2} \pm$ s.e. \\
\hline \multirow[t]{2}{*}{$\overline{\mathrm{LS}}$} & $1^{\text {st }}$ & 7.96 & $0.01 \pm 0.03$ & $0.10 \pm 0.03$ & 7.96 & $0.01 \pm 0.03$ & $0.10 \pm 0.03$ \\
\hline & $2^{\text {nd }}$ & 10.49 & $0.09 \pm 0.05$ & $0.06 \pm 0.04$ & 10.49 & $0.09 \pm 0.05$ & $0.06 \pm 0.04$ \\
\hline AFI & & 78.09 & $0.26 \pm 0.02$ & $0.15 \pm 0.02$ & 78.1 & $0.26 \pm 0.02$ & $0.15 \pm 0.02$ \\
\hline PS & & 0.49 & $0.08 \pm 0.00$ & $0.29 \pm 0.01$ & 5905.9 & $0.09 \pm 0.00$ & $0.29 \pm 0.02$ \\
\hline
\end{tabular}

Table 5. Genetic correlations and their standard errors (upper triangle) and phenotypic correlations (lower triangle) in first and second litter size (LS), age at first insemination (AFI) and pelt size (PS-FIN and PS-DEV) in multitrait analysis.

\begin{tabular}{|c|c|c|c|c|c|}
\hline \multirow[b]{2}{*}{ Trait } & \multirow[b]{2}{*}{ Parity } & \multicolumn{2}{|c|}{ LS } & \multirow[b]{2}{*}{ AFI } & \multirow[b]{2}{*}{ PS-FIN (PS-DEV) } \\
\hline & & 1 & 2 & & \\
\hline \multirow[t]{2}{*}{ LS } & 1 & & $0.76 \pm 0.34$ & $0.07 \pm 0.16$ & $-0.36 \pm 0.11(-0.36 \pm 0.11)$ \\
\hline & 2 & 0.17 & & $0.70 \pm 0.29$ & $-0.27 \pm 0.18(-0.29 \pm 0.18)$ \\
\hline AFI & & 0.06 & 0.11 & & $-0.13 \pm 0.08(-0.13 \pm 0.08)$ \\
\hline PS & & - & - & - & \\
\hline
\end{tabular}


Vol. 16 (2007): 136-146

from zero. Genetic correlations between PS and LS1 and LS2 were unfavorable (Table 5). However, only the correlation between PS-FIN and LS1 and between PS-DEV and LS1 can be considered to differ from zero. Genetic correlation between litter size in second parturition and PS-DEV and PS-FIN was -0.13 and was not significantly different from zero.

Genetic correlation of AFI between LS1 and LS2 was 0.07 and 0.70 , respectively. However, only correlation between AFI and LS2 was considered to differ from zero. Thus, genetically early sexually maturing animals had less pups three weeks after whelping than later maturing animals.

Genetic correlation between PS-FIN and AFI and between PS-DEV and AFI could not be considered to differ from zero. However, there may be weak negative correlation between PS-FIN and AFI and between PS-DEV and AFI.

\section{Genetic trends}

Standardized estimates of breeding values show similar trends for LS1 and LS2 (Fig. 1) between years 1992 and 2002. Genetic trend was mainly downward between years 1992 and 1997, and 1999 and 2002 but it was upward between 1997 and 1999. However, over the whole study period the average trend in LS was slightly downward.
During the study period, AFI had a slightly downward trend (Fig. 2). In other words, according to the genetic trend, first heat became earlier in 2002 than in 1992. Standardized genetic trends of PS-FIN and PS-DEV were identical. Both had a clearly increasing trend throughout the study period.

\section{Transformed auction data}

In 1992 some pelts (less than 1\%) were sorted to class 3, whereas class 2 was not in use. However, this had only mild effect on breeding value estimation. Transformation of PS had negligible effect on the heritability estimates (Table 4) and genetic and phenotypic correlations (Table 5). Moreover, the same correlations differed from zero in PS-FIN and PS-DEV.

Data transformation had only mild effect on standardized breeding values. Naturally, the largest difference ( $\sim 0.2$ standardized index points) was in PS (Fig. 3). Also the standard deviation of difference in standardized indices was clearly highest in PS ( 1.19 point of standardized index). Transformation of PS had no effects on other traits. Differences between standardized breeding values by different transformation methods within the trait were less than \pm 0.1 point of standardized index in all traits except in PS. However, differences were
Fig. 1. Genetic changes in standardized estimates of breeding values by birth year for first (LS1) and second litter size (LS2) in Finnish blue foxes. LS1 $=-\Delta-$, and LS2 $=-\boldsymbol{\Delta}-$

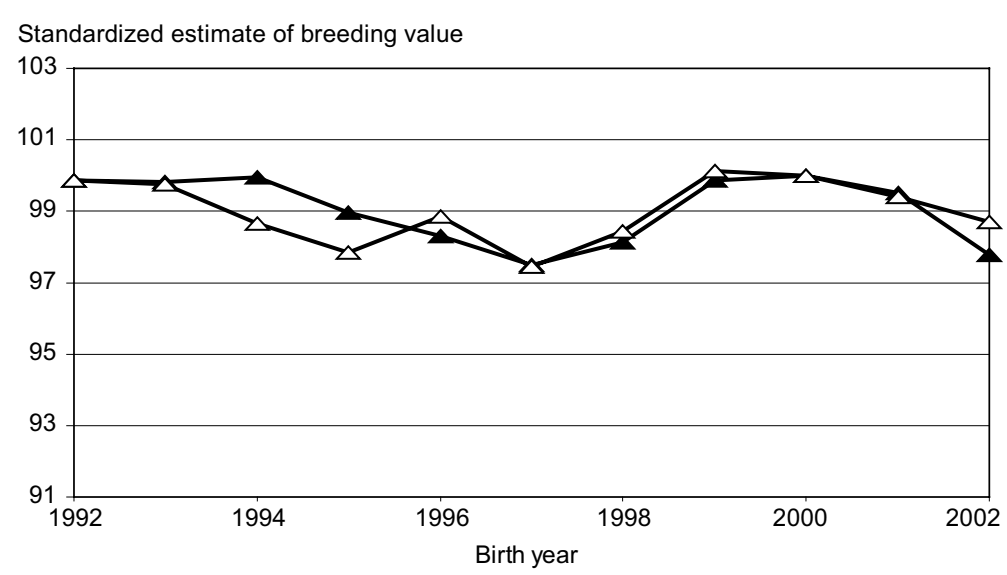


Peura, J. et al. Genetic parameters for Finnish blue fox population

Fig. 2. Genetic changes in standardized estimates of breeding values by birth year for age at first insemination (AFI), pelt size (PS-FIN and PS-DEV) in Finnish blue foxes. AFI $=$ - $\bullet$ PS-FIN and PS-DEV $=$ - - —

Fig. 3. Difference in standardized breeding values of pelt size by birth year between PSFIN and PS-DEV in 19922002. Scale of PS-FIN is the same as in the Finnish breeding programme and PS-DEV was formed from the auction house classes. Solid horizontal line with white circles $=$ mean, thick line $=90 \%$ of differences, vertical lines $=$ minimum and maximum.
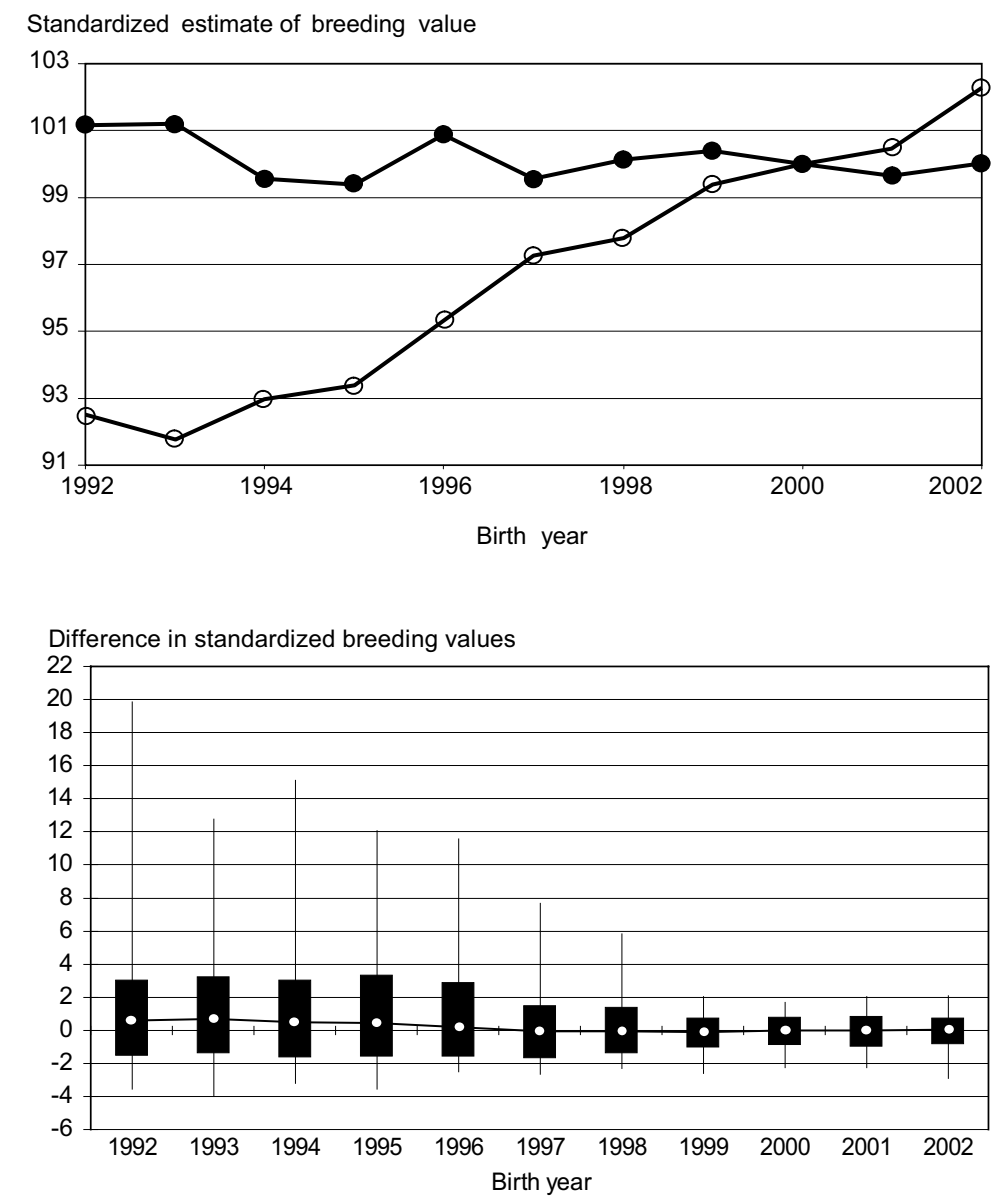

slightly larger in LS than in AFI. In general, PSFIN gave slightly higher breeding value estimates for PS and slightly lower breeding value estimates for fertility traits than PS-DEV. However, correlations between the estimated standardized breeding values within the trait were in all cases more than 0.99 .

\section{Discussion}

\section{Genetic parameters}

Heritability estimates of LS were low which agrees with earlier studies (Nikula 2000, Peura et al. 2004b,
Nordrum 1993). Estimate was lower for LS2 than for LS1.

Heritability estimate for AFI was close to estimates by Peura et al. (2004b) for blue foxes, and close to estimates by Raheja et al. (1989) and Muir et al. (2004) for dairy cattle. On the other hand, Hanenberg et al. (2001) had higher estimates for sows (0.32). However, the comparison to results from pigs or cattle is arbitrary since these are nonseasonal breeders. Proportion of litter variation was similar to that in Peura et al. (2004b). The specific environment that the female pup has together with her litter mates influences AFI in the following production period. Large random litter effect indicates that also genetic maternal effects may be considerable. In the future, it might be reasonable to estimate the genetic maternal effects on AFI. 
Vol. 16 (2007): 136-146

Heritability estimate of PS-FIN was moderate and close to those given by Nikula et al. (2000) and Wierzbicki (2004). Therefore, selection of PS-FIN or PS-DEV can be expected to be relatively effective. The litter environment during the early growth has clear effect on PS-FIN and PS-DEV.

Genetic correlation between PS-FIN and LS1 and between PS-DEV and LS1 were clearly unfavorable. Peura et al. (2004b) had similar estimates between animal size and LS1. If selection is focused on increasing PS-FIN or PS-DEV it will decrease genetic level of the LS1. Impact on the phenotype may be small, because LS has low heritability. However, to avoid decrease in litter size, breeding values of litter size and pelt size should be estimated by a multitrait model. Correlation between PS-FIN and LS2 and between PS-DEV and LS2 were negligible. However, it is obvious that strong selection of PS-FIN or PS-DEV will decrease also genetic level of LS2. Results are in good agreement with the results by Lagerqvist et al. (1994) for minks. Rekilä et al. (2000) concluded that increase of subcutaneous fat increases PS-FIN. Current breeding value evaluation cannot take into account fatness of foxes. This has two consequences: 1) Fat animals have high breeding value in PSFIN. Thus, selection of PS-FIN is likely to increase fat growth in foxes, which may increase feed cost per pelt. 2) Fat foxes have to loose more weight before mating season. Animals with high weight loss will have fertility problems in the spring. The problems are likely to be greater for young females than for older females because of more intensive feeding. In the future, proper methods to account for fatness of foxes in breeding value evaluation needs to be studied. Fatness may have large impact on genetic correlation between PS-FIN and litter size.

Genetic correlation between PS-FIN and AFI and between PS-DEV and AFI did not differ from zero. However, Peura et al. (2004b) had slightly higher genetic correlation $(-0.20)$ between animal size and AFI, which supports the conclusion that there might be low genetic correlation also between PS-FIN and AFI and between PS-DEV and AFI. In other words, large females tend to come into heat sooner than small females. Age at first insemination, litter size and animal size constitute an interesting genetic triangle: according to Peura et al. (2004b), genetic correlation between AFI and LS is about 0.30 . Correspondingly, Serenius et al. (2004) estimated positive genetic correlation between sow's age at first farrowing (AFF) and number of piglets born alive (0.26) and between AFF and number of piglets weaned (0.24) for Finnish Large White pigs. However, for Finnish Landrace the corresponding correlations were negative $(-0.27$ and -0.07 , respectively). Increase in animal size may decrease LS due to unfavorable genetic correlation between animal size and LS. Hence, increase in animal size decreases AFI due to negative correlation, which again decreases LS due to positive genetic correlation between AFI and LS.

Genetic correlation between LS1 and LS2 was high. However, it was clearly less than unity. Moreover, variances of random effects and heritabilities were not equal. In other words, the assumptions of repeatability model (Falconer \& Mckay 1996) were not fulfilled. In addition, the heavy weight loss before mating season, discussed above, is likely to be mainly problem of young females. Therefore, LS1 and LS2 should be considered as different traits.

\section{Genetic trends during the study period}

Sharp upward trend in the estimates of breeding values for PS-FIN and PS-DEV proves that PS-FIN has had high weight in the selection of breeding animals. High economic importance (Lohi 2002, Peura et al. 2004a) and the moderate heritability have lead to substantial increase in PS-FIN during the last decade. However, the genetic change cannot fully explain the large increase of PS-FIN in the Finnish blue fox population. One reason for this increase may be the feeding practices leading to increased fatness of blue foxes.

Blue foxes are traditionally fed almost ad $l i$ bitum. In Finland, strict environmental regulations have caused pressure to decrease protein and phosphorus content in fur animal feed during the last decade. However, when protein content has decreased, fat content has increased. According to 
Peura, J. et al. Genetic parameters for Finnish blue fox population

the feed laboratory of Finnish Fur Breeders Association, proportion of energy from protein and carbohydrate in the total metabolic energy has slightly decreased $(\sim 0.11$ and $\sim 0.37$ percentage-unit per year, respectively) and share of fat in metabolic energy has clearly increased $(\sim 0.5$ percentage-unit per year) in feed between 1992 and 2002. At the same time, average amount of metabolic energy in feed has slightly increased ( $\sim 9.3 \mathrm{kcal}$ per $\mathrm{kg}$ DM per year, Finsk Pälstidskrift 1994-2004). This may have accelerated the upward trend in PS. There might also be genotype by environment interaction on PS at different fat content levels.

Direction and magnitude of genetic change in LS1 and LS2 has varied greatly between 1992 and 2002. However, LS1 has mainly decreased. Although the unfavorable genetic correlation between PS and LS seemed low, the high selection weight on PS has prevented genetic improvement in LS.

Breeding values are not estimated for AFI in the current Finnish breeding scheme for blue foxes. However, most farmers make phenotypic selection according to AFI. In the future, it might be justified to include AFI in multitrait breeding value evaluation to support improvement in traits with economic importance. For example, there was slight downward trend in AFI during the study period, which is probably due to low negative genetic correlation between PS and AFI.

\section{Effect of transformation}

The effect of alternative transformation on PS (PS-DEV) was negligible. As expected, transformation affected only breeding value estimates of PS. Currently used scoring (PS-FIN) seems to give slight overestimation of breeding values of PS (Fig 1) and slight underestimation of breeding values of LS. The overestimation is probably caused by overestimation of the length of pelts in the class with longest pelts. Moreover, the underestimation is probably caused by negative genetic correlation between PS and LS. However, implications for practical breeding value evaluation are negligible. The small effect of transformation is probably due to quantitative nature of the trait also in the Finnish Fur Sales size classes.

Figure 3 illustrates effect of including the new size class in auction seasons 1997-1998 and 1999-2000. During season 1996-1997, the pelts longer than $124 \mathrm{~cm}$ were assigned to class 30 , but in season 1997-1998 they were classified to class 40. Similarly, pelts longer than $133 \mathrm{~cm}$ were assigned to class 40 in season 1998-1999, but in season 1999-2000 they were put into a class 50 . This diminished the difference in standardized breeding values between FIN and TRANSF in 1997 and 1999. The effect was larger in 1997 because the proportion of class 30 decreased within one auction season from $59 \%$ to $44 \%$. In 1999 , the change was not as dramatic.

\section{Conclusions}

There was unfavorable genetic correlation between PS-FIN and LS1 and between PS-DEV and LS1. There has been high selection pressure to increase PS-FIN. This has substantially increased PS-FIN and may have decreased LS1 and LS2 between 1992 and 2002. In the future, breeding value evaluation of PS-FIN and LS should be carried out simultaneously using a multitrait model. Inclusion of AFI in this multitrait breeding value evaluation to support improvement of traits with economic importance may be reasonable.

Transformed auction house observations (PSDEV) and currently used data (PS-FIN) gave nearly similar estimates of genetic parameters and standardized breeding values. Use of PS-DEV instead of PS-FIN had negligible effect on genetic parameters and standardized breeding value estimates of PS, LS1 and LS2 and AFI. Thus, the current data transformation method for PS (PS-FIN) is acceptable. However, effect of data transformation method on other studied pelt character traits needs to be studied. 


\section{References}

ATE-Applied Engineering Ltd, Finland, 2003. Automated blue fox colour shading. European Integrated Machine Vision 2: 14-15.

Falconer, D.S. \& Mckay, T.F.C. 1996. Introduction to quantitative genetics. $4^{\text {th }}$ Edition. Longman, New York, 464 p. ISBN 0582-24302-52.

Farstad, W. 1992. Reproduction in the blue fox vixen (Alopex lagopus). In: Tauson, A.-H., Valtonen, M. (eds.) Reproduction in Carnivorous Fur Bearing Animals. In: NJFUtredning Rapport 75: 119-133.

Hanenberg, E.H.A.T., Knol, E.F. \& Merks, J.W.M. 2001. Estimates of genetic parameters for reproduction traits at different parities in Dutch Landrace pigs. Livestock Production Science 69: 179-186.

Lagerkvist, G., Johansson, K. \& Lundeheim, M. 1994. Selection for litter size, body weight, and pelt quality in mink (Mustela vison): correlated responses. Journal of Animal Science 72: 1126-1137.

Lohi, O. 2004. Analyses of pelt prices. Finnish production. Season 2003/2004. NJF Section for Fur Animals, Fur Animal Reports. $10 \mathrm{p}$.

Lohi, O. 2002. Analyses of pelt prices. Finnish production. Season 2001/2002. NJF utredningar-Rapporter. Subsection for Pelsdyr/Avlsudvalget. $10 \mathrm{p}$.

Madsen, P. \& Jensen, J. 2000. A user's quide to DMU, a packade for analyzing multivariate mixed models, Danish Institute of Agricultural Sciences (DIAS). Tjele, Denmark. Mimeo $22 \mathrm{pp}$.

Muir, B.L., Fatehi, J. \& Schaeffer, L.R. 2004. Genetic Relationships Between Persistency and Reproductive Performance in First-Lactation Canadian Holsteins. Journal of Dairy Science 87: 3029-3037.

Nikula, S. 2000. Kettujen luonteen periytyvyys ja yhteys Hedelmällisyysominaisuuksiin. MSc thesis, University of Helsinki. Helsingin Yliopiston kotieläintieteen laitoksen julkaisuja 48.

Nikula, S., Smeds, K., Hietanen, H., Kenttämies, H. \& Ojala, M. 2000. Confident behaviour and production traits - Results from a field study of foxes. In: Murphy, B.D. \& Lohi, O. (eds.). Proceedings of the 7th International Scientific Congress in Fur Animal Production. Part III B Genetics, Kastoria, Greece, 13-15 September 2000. Scientifur, Vol. 24, No. 4. p. 99-102.

Nordrum, N. 1993 Genetic and endocrinological factors influencing reproduction in blue foxes. Agricultural Univer- sity of Norway. Doctor Scientarum Theses 1993: 7.

Peura, J., Serenius, T. \& Strandén, I. 2004a. Economic weights for litter size and skin character traits in Finnish blue fox production. Proceeding of the XXI Genetic Days, 1-3 September 2004, Wroclaw, Poland. Animal Science Papers and Reports Vol. 22, Suppl. 2. 81-86.

Peura J. 2004. Sinikettujen koon ja hedelmällisyysominaisuuksien perinnölliset tunnusluvut. MSc thesis, University of Helsinki. Helsingin Yliopiston kotieläintieteen laitoksen julkaisuja 71.

Peura, J., Strandén, I. \& Mäntysaari, E.A. 2005. Genetics of size traits, fur quality traits and litter size in blue fox. In: Proceedings of the 56th Annual Meeting of European Association for Animal Production. Uppsala, Sweden, 5-8 June 2005. Book of abstracts p. 211.

Peura, J., Strandén, I. \& Smeds, K. 2004b. Genetics of litter size, age at first insemination and animal size in blue fox (Alopex lagopus). In: Urlings, B., Spruijt, B., Ruis, M. \& Boekhorst (eds.), Proceedings from the 8th International Scientific Congress in Fur Animal Production. Part IV-3RP. 'S-Hertogenbosch, The Netherlands, 15-18 September 2004. Scientifur Vol. 28, No. 3. p. 206-210.

Pälsdjurslaboratoriet informerar. Finsk Pälstidskrift 12/1992-12/2004.

Raheja, K.L., Burnside, E.B. \& Schaeffer, L.R. 1989. Heifer fertility and its relationship with cow fertility and production traits in Holstein dairy cattle. Journal of Dairy Science 72: 2665-2669.

Rekilä, T., Korhonen, H., Pölönen, I. \& Harri, M. 2000. Relationships between feed intake, body mass and skin length in blue fox. In: Murphy, B. D. \& Lohi, O. (eds.). Proceedings from the 7th International Scientific Congress in Fur Animal Production. Part III-C Genetics, Kastoria, Greece, 13-15 September 2000. Scientifur Vol. 24, No. 4. p. 155-158.

Serenius, T., Sévon-Aimonen, M.-L., Kause, A., Mäntysaari, E.A. \& Mäki-Tanila, A. 2004. Selection potential of different prolificacy traits in the Finnish Landrace and Large White populations. Acta Agriculturae Scandinavica, Section A, Animal Science 54:36-43.

Wierzbicki, H. 2004. Breeding value evaluation in Polish fur animals: Estimates of direct heritability and portion of litter variation of fur coat and reproduction traits. Czech Journal of Animal Science 49: 474-482. 
Peura, J. et al. Genetic parameters for Finnish blue fox population

\title{
SELOSTUS
}

\section{Geneettinen vaihtelu Suomen sinikettupopulaatiossa: tarkastelussa pentuekoko, ikä ensimmäisessä siemennyksessä ja nahan koko}

\author{
Jussi Peura, Ismo Strandén ja Esa A. Mäntysaari
}

MTT Biotekniikka-ja elintarviketutkimus

\begin{abstract}
Suomalaisten sinikettujen nahan koko on kasvanut huomattavasti viimeisen vuosikymmenen aikana. Toisaalta pentuekoko on pienentynyt hieman 1990-luvun puolivälin jälkeen. Tässä tutkimuksessa arvioitiin useita ominaisuuksia käsittäneellä eläinmallilla seuraavien ominaisuuksien geneettistä vaihtelua: pentuekoko ensimmäisessä ja toisessa penikoinnissa, ikä ensimmäisessä siemennyksessä sekä nahan koko. Pentuekoon periytyvyydeksi saatiin 0,08 . Periytyvyyden arvioitiin
\end{abstract}

olevan ensimmäistä kertaa siemennettäessä iän osalta 0,15 ja pentuekoon osalta 0,29 . Geneettinen korrelaatio nahan koon ja ensimmäisen pentuekoon välillä oli - 0,30 ja ensimmäisen ja toisen pentuekoon välillä 0,76 . Kun tarkasteltavina ominaisuuksina olivat toinen pentuekoko ja ikä ensimmäisessä siemennyksessä, geneettinen korrelaatio oli 0,70 . Näin ollen hedelmällisyyden ja nahan koon välillä on jalostuksen kannalta epäsuotuisa geneettinen korrelaatio. 